\title{
Reform of The Law of Inheritance in Turkey and Tunisia
}

\author{
Kiki Adnan Muzaki ${ }^{1}$, Asep Saepudin Jahar², Muhammad Amin Suma
}

\begin{abstract}
Reform of The Law of Inheritance in Turkey and Tunisia. This study examines the reform of the law of inheritance in Turkey and Tunisia. Both countries reinterpret the law of inheritance based on the current social context where the changes of social structure particularly related to gender issues encourage changes in its implementation. Applying the library research method, this study aims at comparing the law of inheritance in Turkey and Tunisia and illustrating that the Sharia law associated with social issues is adapted to and reinterpreted according to the needs of the people. As the result, the study draws some conclusion that Turkey grants equal inheritance rights to men and women, whereas Tunisia integrates the inheritance legal system described in the Quran with the social context. This happens since Turkey has been subject to total secularisation and has caused a conflict with the opposition since the beginning of its formation. In the meantime, Tunisia has attempted to avoid a conflict with the traditionalists. To that end, in Tunisia, the opinions of the Mâlikî and Hanafî scholars followed by the majority of the people are adopted and used as a source to formulate the first draft of the civil law.
\end{abstract}

Keywords: Turkey, Tunisia, Law of Inheritance, Reform

Abstrak: Reformasi Hukum Waris di Turki dan Tunisia. Paper ini mengkaji pembaruan hukum waris di Turki dan Tunisia. Kedua negara mereinterpretasi hukum waris berdasarkan konteks sosial saat ini dimana perubahan struktur masyarakat khususnya pola relasi gender mendorong perubahan penerapan hukum waris. Dengan menggunakan metode library research paper ini akan membandingkan antara hukum waris di Turki dan Tunisia dan menggambarkan bahwa hukum Islam yang terkait dengan isu sosial mengalami adaptasi dan reinterpretasi sesuai dengan kebutuhan masyarakatnya. Paper ini menyimpulkan bahwa Turki menyamakan hak waris laki-laki dan perempuan, sementara Tunisia mengkombinasikan antara sistem waris dalam Alquran dan kontak sosial di masyarakat. Hal ini terjadi karena Turki telah melakukan sekulerisasi total dan menghendaki adanya konflik dengan oposisi pada awal pembentukannya. Sedangkan Tunisia tidak menghendaki adanya konflik dengan kaum

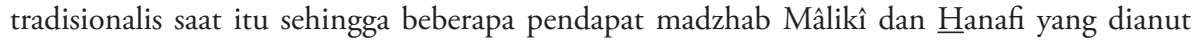
mayoritas masyarakat diadopsi dan digunakan sebagai salah satu sumber perumusan draft awal undang-undang perdata di Tunisia.

Kata Kunci: Turki, Tunisia, Hukum Waris, Pembaharuan.

\footnotetext{
${ }^{1,2}$ Graduate School, UIN Syarif Hidayatullah Jakarta, Jl. Kertamukti No. 5, Pisangan Barat, Ciputat, Tangerang Selatan

${ }^{3}$ Faculty of Sharia, UIN Syarif Hidayatullah Jakarta, Jl. Ir H. Juanda No. 95, Ciputat, Tangerang Selatan

E-mail: ${ }^{1}$ kiki_muzaki19@mhs.uinjkt.ac.id, ${ }^{2}$ asepjahar@uinjkt.ac.id, ${ }^{3}$ aminsuma@uinjkt.ac.id
} 


\section{Introduction}

As a product of ijtihad (independent reasoning) by the classical scholars, Fiqh has been the only legal source having been enforced by the Islamic states and dynasties for many years. Accordingly, all criminal and civil acts are subject to legal consequences based on the ijtihad performed by Muslim scholars referring to the texts in the Qur'an and Hadith. However, the immunity of Sharia law addressed to non-Sharia materials does not last forever. In the middle of the nineteenth century, the Ottoman Empire reformed its state legal and policy systems by adopting the western system which had happened until it finally declared itself as a secular republic. This means, on the one hand, the Shari'ah law is not the main law to be applied in Turkey. ${ }^{1}$ Such a legal approach in the sense that religious norms not being superior to the state system is followed by Tunisia. The reforms of the legal system were directly influenced by the modernization of law in the West. A lot of legal materials on the reform of Sharia law in Tunisia have drawn controversy such as the ban on polygamy and abolition of the right to Ijbar (marriage under compulsion). This is due to the willingness of the Tunisian president, Bourguiba, who expects secularism in Tunisia and the judicial unification and formulation of modern family laws. ${ }^{2}$

The law of inheritance is one of the important materials in reforming the family laws in Muslim countries. There are two inheritance legal patterns known in Muslim countries, one of which directly refers to the texts in the Qur'an, man is entitled to receive two portions compared to woman, ${ }^{3}$ and the other suggests that both men and women have equal

\footnotetext{
${ }^{1}$ Ahmad Bunyan Wahib, 'Reformasi Hukum Keluarga Di Dunia Muslim', Ijtihad : Jurnal Wacana Hukum Islam Dan Kemanusiaan, 14.1 (2014), 1 <https://doi.org/10.18326/ijtihad. v14i1.1-19>.

2 Ratih Lusiani Bancin, 'Hukum Keluarga Islam Di Tunisia', Jurnal: Penelitian Medan Agama, 9.2 (2018), 283-308.

${ }^{3}$ In plain view, such a share seems unjust and to benefit only one party. However, because of the meaning of justice, this is not entirely true. According to Aristotle, justice has two meanings; distributive Justice, the justice in this sense is giving a person's rights based on their respective portions. In other words, equality is not a principle and standard of justice. The second is commutative Justice. The justice in this meaning is to give everyone the same rights regardless of who he/she is. Here, equality is the main principle. See David L. Osborn, 'Aristotle's Conception of Justice', Notre Dame Law Review, 17.2 (1942), 129-43.
} 
shares. Here, Tunisia applies the first pattern, whereas Turkey practices the second one. This is certainly an interesting case to study considering that both are secular countries, but they take different paths in dealing with inheritance legal issues. Many studies on Muslim law reforms have been conducted by some students, among others, are Miftahul Huda ${ }^{4}$ and Ahmad Bunyan. ${ }^{5}$ They studied family law reform and provided an overview of the pattern of the legal reform in Muslim countries. Fuad Mahsun has also researched the law of inheritance in Turkey. However, his research focuses more on the impact of secularization on the legal reform and left the important issue on inheritance. ${ }^{6}$ Further, research conducted by Lilik Andaryuni illustrates the law of inheritance in Turkey and Somalia in more detail. She has attempted to compare the two countries that apply the 1:1 formula in the distribution of inheritance. ${ }^{7}$

The research method used in this study is library research referring to literature and scientific journals dealing with the law of inheritance. After the research data is collected, an analysis and comparison are made in comparing the family laws in two countries in highlighting vertical and horizontal approaches. The vertical approach is used to check the consistency, modification, and adaptation of the implementation of Sharia and positive law. Meanwhile, the horizontal approach is applied to compare the interpretation and application of Sharia between the two countries.

\section{Typology of the Sharia Law Reform in Muslim Countries}

In his book, Family Law Reform in The Muslim World, Tahir Mahmood mentions in reforming the Sharia law, Muslim countries are divided into three groups; 1) countries that follow the opinions of salaf

${ }^{4}$ Miftahul Huda, 'Ragam Bangunan Perundang-Undangan Hukum Keluarga Di NegeraNegara Muslim Modern', Al-Manahij: Jurnal Kajian Hukum Islam, 11.1 (2017), 49-60 <https:// doi.org/10.24090/mnh.v11i1.1267>.

${ }_{5}$ Wahib.

${ }^{6}$ Mahsun Fuad, 'Dinamika Sekularisasi Dan Pembaharuan Hukum Waris Islam Di Turki', Al-Mabsûth, 13.2 (2019), 11-22 <https://doi.org/10.5281/ZENODO.3690544>.

${ }^{7}$ Lilik Andaryuni, 'Pembaharuan Hukum Kewarisan Islam Di Turki Dan Somalia', Hikmah, 14.1 (2018), 145-81. 
scholars and do not make any reforms or changes, 2) countries that completely ignore the Sharia family law and replace it with modern law, and 3) countries that implement the Sharia family law reformed with various regulations and provisions. ${ }^{8}$

Similarly, Otto states in his book Sharia and National Law in Muslim countries concerning law reforms. There are three positive legal systems in Muslim countries; 1) a mixed system, that is the Sharia law becomes one of the important materials in the formulation of state laws. This system is adopted by the majority of Muslim countries in the world, 2) classical Sharia system, that is the Sharia law becomes the only source that applies in the country. This system is only adopted by a few Muslim countries, and 3) the secular system, indicating no religious intervention in state affairs, politics, and law. To this model, Sharia law is not enforced.'

Otto sheds light on the country that exclusively applies sharia law in its literal and original mode directly derived from the Quran and the Sunna. He called this mode of sharia system the classical Sharia system. Saudi Arabia, a country founded by Alu Su'ud that enforces the laws according to the Qur'an, Hadith, and Hanbali school of thought. ${ }^{10}$ This legal system owes greatly to the hand of Muhammad Ibn 'Abdul Wahab. The fundamental approach of law was also supported by 'Abdullah Ibn 'Abdul Rahman Sulaim served as the city Governor had great access to Muhammad Ibn Su'ud. To his advantage, he could bring Muhammad Ibn 'Abdul Wahhab to get close to him. Muhammad Ibn Su'ud accepted his da'wah and eventually protected him under his power politically and militarily. Unsurprisingly, Muhammad Ibn 'Abdul Wahhab's da'wah movement was so successful and reached its peak when the Saudi Arabian state was formed, rebelling against the Ottoman dynasty and its teachings. In addition, his da'wah was used as the main basis in the formulation

${ }^{8}$ Tahir Mahmood, Family Law Reform in The Muslim World (New Delhi: The Indian Law Institute, 1972).

${ }^{9}$ Jan Michiel Otto, Sharia and National Law in Muslim Countries Tensions and Opportunities for Dutch and EU Foreign Policy (Leiden: Leiden University Press, 2008).

${ }^{10}$ Agustina Nurhayati, 'Politik Hukum (Legislasi) Hukum Keluarga Di Saudi Arabia', Ijtimaiyya, 7.1 (2014), 67-81 <https://doi.org/10.24042/ijpmi.v7i1.918>. 
of state law. ${ }^{11}$ To this end, the strong role of Wahabism has directly blocked family law reform in Saudi Arabia as the government fully supports the Salafi ideology which does not welcome any changes and reform in the Sharia law.

In the meantime, Turkey and Albania are among the countries that implement the secular Sharia system. The legal system in effect in both countries is not classical Sharia, but western legal materials instead. This includes Tanzania which codifies special civil laws applied to all citizens. ${ }^{12}$ The typology widely used in Muslim countries, including Egypt, Malaysia, Indonesia, Pakistan, Morocco, Nigeria, Sudan, and others is a mixed system. ${ }^{13}$ Each country has certain factors behind the materials to reform the family law. In Egypt, for example, maslahah (public interest) is considered as one of the factors in the formulation of washiah wâjibah. According to Ibn Hazm, a will for relatives who are mahjub (blocked) due to the presence of another heir is mandatory, regardless of their willingness to take it or to leave it; the judge has the authority to grant this will to the rightful. ${ }^{14}$ In Indonesia, the formulation of Harta Gono Gini (joint property) in the Islamic Legal Compilation is influenced by living tradition where wife and husband have an equal right and share in managing the family life. The term gono gini itself derives from Javanese tradition, meaning wife and husband share equal rights. ${ }^{15}$ In short, these countries have made several adjustments to the classical Sharia system by adding special provisions that are deemed necessary and considered important to enforce.

${ }^{11}$ Arrazy Hasyim, Teologi Muslim Puritan, Geneologi dan Ajaran Salafi, 1st edn (Ciputat: Maktabah Darus Sunnah, 2017); Nâshir Ibn 'Abdul Karîm, Islâmiyyah lâ Wahabiyah (Saudi Arabia: Dâr al-Kunûz al-Asybiliyah, 2004).

${ }^{12}$ Mahmood.

${ }^{13}$ Otto, Sharia and National Law in Muslim Countries Tensions and Opportunities for Dutch and EU Foreign Policy.

${ }_{14}$ Zulfia Hanum and Alfi Syahr, 'Wasiat Wajibah Sebagai Wujud Penyelesaian Perkara Waris Beda Agama Dalam Perkembangan Sosial Masyarakat', Holistik, 1.2 (2016), pp. 123-33 <https://doi.org/http://dx.doi.org/10.24235/holistik.v1i2.905>

${ }^{15}$ Uswatun Hasanah and Chitra Latiffani, 'Kajian Pembagian Harta Gono Gini Menurut Kompilasi Hukum Islam', Journal of Science and Social Research, 1.2 (2018), 137-40 <https:// doi.org/10.33330/jssr.v1i2.220>. 
Tahir Mahmood mentions four methods to reform the Sharia law; 1) takhayyur, tending to an opinion delivered by a certain Muslim scholar (Ulema) over the others, 2) talfiq, combining several opinions by different scholars in several cases, 3) siyâsah shar'iyah, adding certain provisions in the Sharia law by state authorities, and 4) ijtihad, reinterpreting certain laws which are performed by Muslim scholars and results in ijtihad products in line with the social conditions and changes of a country. ${ }^{16}$

Indonesia has used these methods in reforming the Sharia law. In polygamy cases, for example, it uses siyâsah shar'iyah by applying several requirements to meet before practicing polygamy. The requirements include; 1) wife's consent, 2) a guarantee that the husband can meet the needs of his wives and children, and 3) a guarantee that the husband will treat all of his wives and children fairly and equally. After being considered eligible, the religious court will grant permission to a husband to practice polygamy. It means, without getting the wife's permission, the marriage has no legal force. ${ }^{17}$ Article 71 of the Islamic Legal Compilation even mentions that the marriage can be canceled once legal permission has not been fulfilled. In contrast to Indonesia, Tunisia applies the ijtihad method to deal with polygamy issues by referring to the opinion of the reformist figure, Thâhir Haddâd (1899-1935 AD). He reinterprets the texts about polygamy in the Qur'an and states a polygamy is a form of tadarruj fi tashri in which its legitimacy is no longer relevant in the present. ${ }^{18}$ Therefore, polygamy is strictly banned in Tunisia. Those who break this law will be faced with imprisonment.

\section{History of the Law Reform in Turkey}

The formation of the Turkish state took place after the collapse of the Ottoman Empire which had controlled the mainland of the Middle East and East Africa for centuries (1342-1924 AD). The Ottoman Empire

${ }^{16}$ Mahmood.

${ }^{17}$ Edi Darmawijaya, 'Poligami Dalam Hukum Islam Dan Hukum Positif; Tinjauan Hukum Keluarga Turki, Tunisia Dan Indonesia', Gender Equality, 1.1 (2015), 27-38.

${ }^{18}$ Al-Thâhir Haddâd, Imra'atunâ Fî̀ Al-Sharî'ah Wa-Al-Mujtama' (Cairo: Dâr al-Bayân al-Mishrî, 2011). 
was the strongest empire in the world during its heyday. It was able to overthrow the Roman Empire and conquer Constantinople, but its glory had slowly faded when the Portuguese and Russian Empires came to invade. The territories under the Ottoman Empire, one after the other, separated themselves and caused its power to get weaker. ${ }^{19}$ In addition, after the death of Solomon I who held the al-Qannuni title, his dignity was fading away and weakening. This resulted in the people's distrust of the caliphate. Besides, after repeatedly losing wars against Europe, the Ottoman Empire had agreed to sign an accord that was detrimental and narrowed its territory. ${ }^{20}$

The peak collapse was when the secular Turkish state was formed and declared in 1923 by the Grand National Assembly of Turkey, with Mustafa Kemal Atatürk (1923-1938 AD) as the first president. In 1922, the National Assembly formally wiped out the sultanate (the Decree No. 308/1922, November 1-2). In turn, the caliphate system was abolished (see Law No. 431/1924) and reformed with the republic system. This means abolishing the caliphate is a concrete government's commitment to bring Turkey into a secular country. The concept of submission to God, which was originally at the top of the state principle, has been replaced by the concept of loyalty to the state. ${ }^{21}$

The Sharia law reform in Turkey began with the formation of the Tanzîmat as a result of European expansion on several Ottoman Empire territories. This has resulted in the splitting of the Empire officials into two groups; the conservative group has strongly rejected the adoption of the western political system and law. They believe that religion and politics are inseparable. The second is the reformist group who expect a large-scale reform of the state system as they believe that the

${ }^{19}$ Vita Fitria, 'Hukum Keluarga Di Turki Sebagai Upaya Perdana Pembaharuan Hukum Islam', HUMANIKA, 12.1 (2015), 1-15 <https://doi.org/10.21831/hum.v12i1.3648>; Sharia Incorporated; A Comparative Overview of the Legal Systems of Twelve Muslim Countries in Past and Present, ed. by Jan Michiel Otto, Law, Governance, and Development Research (Leiden: Leiden Univ. Press, 2010).

${ }^{20}$ Dian Andriasari, 'Studi Komparatif Tentang Zina Dalam Hukum Indonesia Dan Hukum Turki', Syiar Hukum, 13.3 (2011), 265-79.

${ }^{21}$ Otto, Sharia Incorporated; A Comparative Overview of the Legal Systems of Twelve Muslim Countries in Past and Present. 
adoption of the western system in terms of military, law, administration, economy, and education is a must to build a state. In addition, they also suspect that the legal system in the Ottoman Empire consists of two different legal systems. ${ }^{22}$ The Empire has accidentally adopted the western system in implementing the applicable law. ${ }^{23}$ The modernization of the Ottoman Empire then continued and was supported by Mahmud II (1807-1839), with the help of Grand Vizier Mustafa Reshit Pasha. He made reforms in different aspects including education and codification of law. The Tanzimat institution developed by Reshit Pasha was then formed in $1839 .{ }^{24}$

Since 1876, the Ottoman Empire has enacted the Islamic Civil Law (Majallat al-Ahkam al-Adliya) which contains fiqh laws according to Muslim scholars from various schools and adopted from the West. However, the Code does not include the family law and law of inheritance. ${ }^{25}$ The family law reform in Turkey began with the revision of marriage and divorce laws in 1915 which was later codified in 1917. Such action was taken because the government considered that the Sharia law referring to the Hanafi school of thought followed by the majority of society had harmed some parties, especially women. Most scholars in the school argued that a wife could not file for divorce as it was a man's right. For this reason, in 1915 the Ottoman government issued two decisions regarding the right of women to file for divorce under the king's order. First, if the husband has left the wife for years, she has the right to file for divorce. This is in line with the opinion of Maliki and Hanbali. Second, if the husband is proven to have a

${ }^{22}$ One of the pieces of evidence in the adoption of western law that has been carried out by the Ottoman Empire is the existence of the authority of the ruler to make the applicable law based on his ijtihad. This law is commonly referred to as qânûn. See Otto, Sharia Incorporated; A Comparative Overview of the Legal Systems of Twelve Muslim Countries in Past and Present.

${ }^{23}$ Otto, Sharia Incorporated; A Comparative Overview of the Legal Systems of Twelve Muslim Countries in Past and Present.

${ }^{24}$ Otto, Sharia Incorporated; A Comparative Overview of the Legal Systems of Twelve Muslim Countries.., h. 235Otto, Sharia Incorporated; A Comparative Overview of the Legal Systems of Twelve Muslim Countries in Past and Present; Abu Yazid Adnan Quthny, 'Reformasi Hukum Keluarga Islam Turki (Status Poligami Dalam Perspektif Teori Linguistik-Semantik Muhammad Shahrur)', Asy-Syariah, 2.2 (2016), 1-34.

${ }^{25}$ Fitria. 
dangerous disease, such as leprosy, the wife can file for divorce on the condition that she does not know his disease before the marriage is carried out. The government soon sensed the urgency to codify the family law wholly. In turn, the Ottoman Law of Family Right (Qânun al-Huquq al-'Aila) was issued in 1917. This is the first family law to be made a positive law in an Islamic state. ${ }^{26}$

The Ottoman Law of Family Right which was codified in 1917 did not only adopt the opinion of the Hanafi scholars but also referred to the opinions of Maliki, Shafi'i, and Hanbali scholars. Unfortunately, this law did not last long as Turkey was declared as a secular republic by Mustafa Kemal Atatürk as the first president in 1923. It then experienced total secularism in which the applicable legal system did not refer to the Sharia law at all. In exchange, it adopted the Swiss civil law which took effect in $1927 .{ }^{27}$

In 1924, a regulation (qânûn) to abolish the position of shaikh Islam and the Ministry of Religion which was later replaced by diyanet (the Directorate of Religious Affairs) under the direct authority of the Prime Minister was made. The principle of separating religion from politics was further emphasized in the 1926's Criminal Code which stipulates penalties for those who abuse religion, religious sentiments, or anything for that matter. Nevertheless, Islam is not completely erased from Turkey. According to Law no. 364/1923 (on October 29) which amends the 1921's Constitution, Islam is still recognized as one of the state religions, and the government is obliged to regulate religious affairs including Islam. ${ }^{28}$

The regulations on religious affairs are decided at the Diyanet institution, particularly the Office of Religious Affairs which is assigned to regulate religious affairs including faith, worship, and moral principles, management on places of worship, and alike. This is in line with article

${ }^{26}$ Mahmood; Fitriyani Zein, 'Kekerasan Dalam Perkawinan Dan Nusyuz Dalam Hukum Keluarga Di Turki, Malaysia, Sudan, Yordan Dan Indonesia', SALAM: Jurnal Sosial Dan Budaya Syar-i, 4.1 (2017), 121-36 <https://doi.org/10.15408/sjsbs.v4i3.10290>.

${ }^{27}$ Wahib. p. 7.

${ }^{28}$ Otto, Sharia Incorporated; A Comparative Overview of the Legal Systems of Twelve Muslim Countries in Past and Present. 
136 in the 1982's constitution as follows:

"The Office of Religious Affairs, which is within the general administration, shall exercise its duties prescribed in its particular law, following the principles of secularism, removed from all political views and ideas, and aiming at national solidarity and integrity."

The Office of Religious Affairs carries out its duties stipulated in the Constitution in particular. This must be done according to the principle of secularism, eliminating any political views and ideas, and aiming at national solidarity and integrity. In practice, the existence of this diyanet actually results in pros and cons. The first group believes that religious affairs must be managed by each community, whereas the second suggests that diyanet should not regulate different religions as it will only trigger religious conflict. As of last, the third group, which is the majority of people in Turkey, fully supports the existence of diyanet. ${ }^{30}$

The diyanet which has its head office in Ankara was founded in 1975 and is assigned to enlighten the public concerning religion, to manage mosque construction, to open health facilities for the poor, and to distribute zakat among people in order to help the disadvantaged people. ${ }^{31}$

\section{History of the Law Reform in Tunisia}

Tunisia has its privileges in gaining its independence. It is the only North African country that could break free from authoritarian rule without involving civil war. ${ }^{32}$ At first, it was an autonomous region of the Ottoman Empire and became a French commonwealth state based on the Conventions of La Marsa in 1883. On March 20, 1956, it gained its independence. ${ }^{33}$

${ }^{29}$ Otto, Sharia Incorporated; A Comparative Overview of the Legal Systems of Twelve Muslim Countries in Past and Present.

${ }^{30}$ Otto, Sharia Incorporated; A Comparative Overview of the Legal Systems of Twelve Muslim Countries in Past and Present.

${ }^{31}$ Ömer Turan, 'The Turkish Diyanet Foundation.', Muslim World, 98.2/3 (2008), 370-84.

${ }^{32}$ José S Vericat, Tunisia, Women's Struggle for Citizenship, Civil Society and Constitution Making after the Arab Uprisings (International Peace Institute, 27 June 2017).

${ }^{33}$ Mahmood; 'The Tunisian Constitution', Middle East Journal, 13.4 (1959), 443-48. 
The family law reform in Tunisia began in the pre-independence era and was initiated by Shaikh Islam Muhammad Ju'ait. In 1947, he formed a committee consisting of academics and legal experts to formulate a legal draft which was later named Lẩihat Majallat al-Ahkâm al-Shar'iyyah. This draft was then submitted to the government at the time. However, several issues arose and prevented this draft from being officially published. ${ }^{34}$

After the independence, the Tunisian government under the leadership of Habib Bourguiba (1957-1987 AD) created a new project to formulate a more modern draft of the family law. Such a project was authorized to the scholars, academics, and court. In formulating the draft, the drafting team referred to three guidelines; 1) unifying the justice system for all Tunisian people, 2) modernizing and reforming the family law, and 3) avoiding conflict with the traditionalists by formulating the draft based on the Sharia and adopting the figh of Mâlikî and Hanafî as the majority of Tunisian society's schools of thought and the opinions of other schools of thought. After completing the legal draft, it was then submitted to the government and officially enforced under the name of the Code of Personal Status or Majallat al-Akhwâl al-Shakhshiyyah in 1956. This code consists of 170 articles in 12 chapters; marriage, divorce, iddah (waiting period), livelihood, care and custody, guardianship, abandoned children, missing persons,

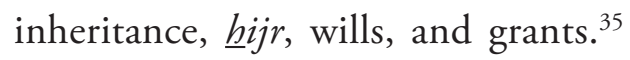

\section{A Symbiosis of the Law of Inheritance in Turkey and Tunisia}

In general, the concept of inheritance in the Sharia law gives a man more rights than a woman, with a $2: 1$ ratio. ${ }^{36}$ It is not without reason. The wisdom behind the ratio is because a man as a husband

\footnotetext{
${ }^{34} \mathrm{~J}$ N D Anderson, 'The Tunisian Law of Personal Status', The International and Comparative Law Quarterly, 7.2 (1958), 262-79.

35 Anderson; Bancin.

36 Allah said in the Qur'an:
}

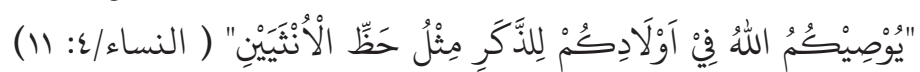
Allah commands you regarding your children: the share of the male will be twice that of the female. 
will be responsible for supporting his family and give dowry to the woman when they are married. In the meantime, a woman as a wife does not have the obligation to earn a living, even though some are willing to do so. This is only her gesture of kindness to help her husband with the family finances and is not her obligation. For this reason, the share ratio in which a man gets more than a woman is considered proportional and according to their respective needs. ${ }^{37}$ However, this concept has often been questioned by several parties. The companions, for example, once asked Prophet Muhammad through Umm Salamah: "O Messenger of Allah! Why are men [allowed or even ordered] to fight, while we, women, not included? [Is that the reason why we only get half of the inheritance?" Surah an-Nisa: $32^{38}$ which prohibits the jealousy of women towards men in terms of inheritance share was then revealed. ${ }^{39}$ Further, some have attempted to change the 2:1 ratio into 1: 1 because in today's context earning a living and supporting family finances is no longer the monopoly of men as it happened in the past. To that end, the right to get an equal portion of the inheritance seems fairer. ${ }^{40}$ If, in the end, the enforcement of equal inheritance rights for men and women in several places happens, it is not based on what is written in the texts (dalîl naqlî), but refers to ijtihad by considering the social context and conditions as the texts in the Qur'an and Hadith clearly mentions that men are entitled to two portions of the inheritance compared to women. ${ }^{41}$

${ }^{37}$ Wahbah Al-Zuhailî, Al-Tafsîr al-Munîr Fî al-Aqîdah Wa al-Shariah Wa al-Manhaj (Damaskus: Dâr al-Fikr, 1998).

${ }^{38}$ Allah said in the Qur'an:

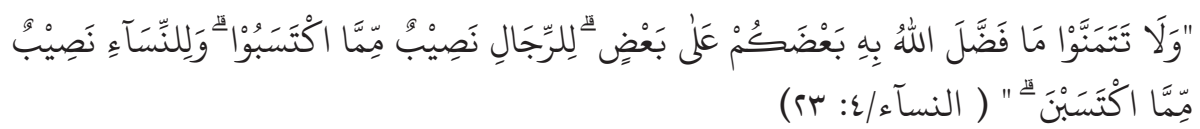

And do not long for things by which Allah has given superiority to some of you over others; for men is the share of what they earn and for women the share from what they earn

${ }^{39}$ Muhammad Amin Suma, Keadilan Hukum Waris Islam Dalam Pendekatan Teks dan Konteks (Jakarta: Rajagrafindo Persada, 2013).

40 Suma.

${ }^{41}$ Suma. 


\section{a. The Law of Inheritance in Turkey}

Referring to the Turkish civil law, men and women have equal rights to inheritance ${ }^{42}$, applying the 1:1 ratio. Prior to the secularization, it implemented the 2: 1 ratio as stated in the Ottoman Law of Family Right (OLFR). The OLFR itself contains the opinions of Muslim scholars from various schools of thought and none of them regards the 1: 1 ratio in the distribution of inheritance. However, after the secularization, the OLFR is no longer valid and replaced by the Turkish Civil Law which equalizes the rights of men and women. ${ }^{43}$

In addition to the ratio in the equality of rights between men and women, the conflict between the Turkish law of inheritance and the Sharia law also occurs in the inheritance rights of adopted children. In the Turkish civil law, an adopted child has the same rights as a biological child who cannot be married to (ma $\underline{\text { ram }}$ ) and also gets inheritance rights. ${ }^{44}$ In contrast, the status of an adopted child in the Sharia law is considered as a foreigner who can be married to and does not get inheritance rights as adoption is not included in one of the asbâb al-irth (the circumstances of inheritance) ${ }^{45}$ Such distinction occurs for the Sharia law is not one of the sources in formulating the laws in this country, although in some ways the Turkish civil law has similarities with the Sharia law, such as the absence of inheritance rights in same-sex marriage. ${ }^{46}$ This is, indeed, in line with the Sharia law which strictly prohibits such marriage. The people of Prophet Lut were even punished for committing such acts. ${ }^{47}$

42 Mahmood.

${ }^{43}$ However, in some remote areas, the inequality in inheritance can be found when a woman receives half of what a man does, or does not get any inheritance rights at all. If, for example, a dispute happens among heirs, the family must internally resolve it and it has nothing to do with the legal structure or state administration. See Otto, Sharia Incorporated; A Comparative Overview of the Legal Systems of Twelve Muslim Countries in Past and Present.

${ }^{44}$ Mahmood.

45 The circumstances of inheritance commonly agreed by Muslim scholars are lineage, marriage, and walâ (the relationship between a former slave and the master). See Wahbah AlZuhailî, Al-Figh al-Islâmî Wa Adillatuh (Damaskus: Dâr al-Fikr).

46 'Succession in Turkey' <http://www.admdlaw.com/succession-in-turkey/\#.Xvk8Bigza01>.

47 The punishment that befell the people of Prophet Lut is the city was turned upside down. See Muhammad Ibn Jarîr al-Thabari, Jâmî̀ al-Bayân Fî̀ Tảwîl al-Qur'ân, ed. by Ahmad Muhammad Shâkir (Beirut: Muassasah al-Risâlah, 2000). 
Another thing which both laws have something in common is in terms of the prohibition on inheriting all assets owned ${ }^{48}$ as the Sharia law limits a maximum of one-third of the assets that can be inherited. ${ }^{49}$

The Turkish civil law also regulates those who are entitled to inheritance. They are divided into three groups: 1) the descendants of the deceased, 2) the parents and their children/brothers and sisters of the deceased, and 3) the grandparents and their children/uncles and aunties of the deceased. These three groups are sorted according to the priority scale. If the first group exists, the other groups are not entitled to get the inheritance rights, meaning when someone dies and has a child, only the child inherits the assets, whereas the parents and grandparents and their children do not have rights. This system only applies if the deceased does not make a will before his death. ${ }^{50}$

As for the spouse, the Turkish civil law (2001) states that all assets (except for personal assets) and assets acquired during a marriage are considered joint ownership. If a husband or a wife dies, the asset is liquidated before the inheritance is determined. The spouse has the right to claim the liquidation and determination of the assets and their share in their marriage. ${ }^{51}$ Suffice to say, it resembles the concept of gono-gini property in Indonesia. The legal logic is syirkah (partnership). Here, the husband and wife work together in building a family so that the assets obtained after marriage are considered joint property and when one of them dies, it must be divided in half before being distributed to the heirs. ${ }^{52}$

48 'Succession in Turkey'.

${ }^{49}$ Prophet Muhammad (peace be upon him) once forbade Sa'ad who was willing to bequeath all of his assets when he was sick. The Prophet then limited it to $1 / 3$ of the assets.

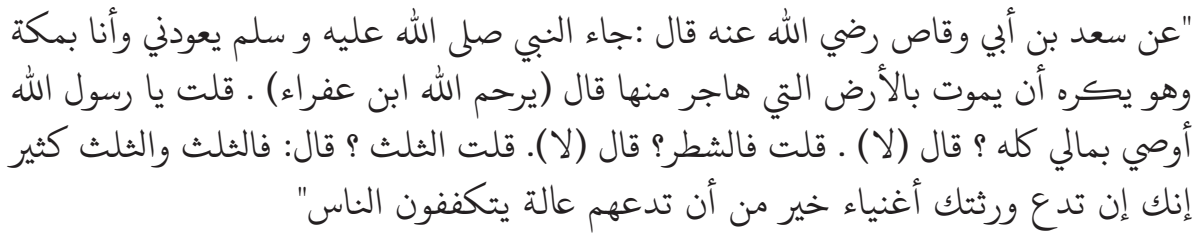

See Muhammad Ibn Ismầil Al-Bukhârî, shahîhh al-Bukhârrî, 3rd edn (Beirut: Dâr Ibn Kathîr, 1987).

50 'Succession in Turkey'.

51 'Succession in Turkey'.

52 'Succession in Turkey'. 
Referring to the above descriptions, several conflicts happen between the Turkish law of inheritance and the Sharia law. This is due to the influence of the Portuguese and Russian Empires that came invading the Ottoman Empire. Therefore, the state officials initiated to reform the state system by adopting the western system in order to reinforce and restore the Empire's power which was gradually weakening. ${ }^{53}$

\section{b. The Law of Inheritance in Tunisia}

In several cases, Tunisia has liberalized the Islamic law reform. It can be seen from some examples including the prohibition of polygamy and the prohibition of remarrying an ex-wife who has got triple repudiation. ${ }^{54}$ Such reform is strongly influenced by the reformist figures, such as Thâhir al- Haddâd with his controversial ideas. According to him, the concept of marriage as instructed by Islam is monogamy. Polygamy is merely a practice of the jahiliah cultures which Islam gradually opposes. Such culture has allowed a man to marry any woman he wants. However, Islam only limits the number of wives to four. ${ }^{55}$ This limitation is a form of tadarruj fi al-shariah which means it is not a definite limit. It was taken for some consideration that if Islam was directly limited to one, it might not be accepted at the time. Besides, Allah said in another verse that it is impossible for a man to treat his women equally. ${ }^{56}$ This

${ }^{53}$ Fitria; Otto, Sharia Incorporated; A Comparative Overview of the Legal Systems of Twelve Muslim Countries in Past and Present.

${ }^{54}$ Bancin.

55 Allah said in the Qur'an:

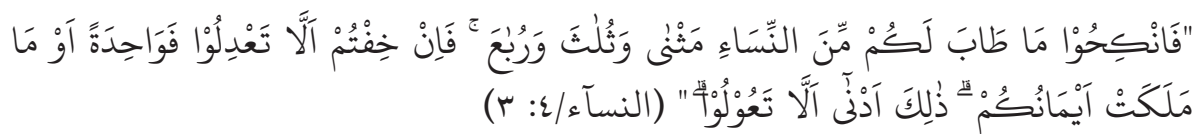

Then marry other women of your choice-two, three, or four. But if you are afraid you will fail to maintain justice, then 'content yourselves with' one or those 'bondwomen' in your possession. This way you are less likely to commit injustice.

${ }^{56}$ Allah said in the Qur'an:

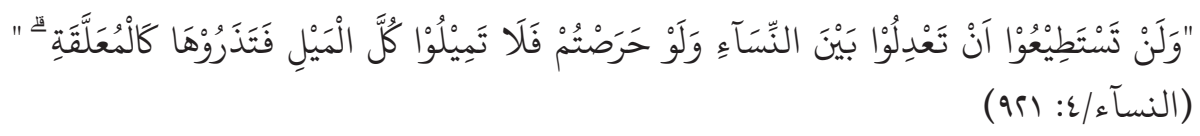

You will never be able to maintain 'emotional' justice between your wives-no matter how keen you are. So do not totally incline towards one leaving the other in suspense 
suggests that the concept of marriage brought by Islam is monogamy and not polygamy. ${ }^{57}$

Interestingly, although in some cases Tunisia has made extreme reforms, in the case of inheritance, it still applies the 2:1 ratio by giving men more portion in the inheritance rights than women. Most of the laws of inheritance applied in the country refer to the codification of the law of inheritance in the Mâlikî School..$^{58}$ Anderson further mentions:

"It seems that the Maliki law of intestate succession has been followed virtually exclusively in Tunisia, even among those families which otherwise observed Hanafi principles-and this is faithfully reflected in the codified"s?

The Malikî school of thought itself claims that men have more rights than women. Imam Mâlik was once asked about a man who died and had sons and daughters. He replied the inheritance right for both of them in the situation is that the men get twice as much as the women. ${ }^{60}$ This means Tunisia does not adopt the opinion of Thâhir al- Haddâd stating men and women have equal rights in getting the portion of the inheritance. According to him, the law of inheritance is also considered as one of the tadarruj fi tashri practices. At the time of Prophet Muhammad (peace be upon him), the share that a woman gets is only a half of that of a man. Such a phenomenon was indeed revolutionary seeing the social conditions at the time did not give women any inheritance rights at all. This indicates giving half to a woman is not a definite limitation that will be valid eternally. Back in the days, the social conditions were patriarchal, which certainly made it impossible to equalize the inheritance rights for women and men. However, in this era when women and men both take part in every aspect of life, some change might need to be done. ${ }^{61}$

\footnotetext{
${ }^{57}$ Haddâd.

${ }^{58}$ Mahmood.

59 Anderson., h. 274.

${ }^{60}$ Mâlik Ibn Anas, Al-Mudawwanah (Libanon: Dâr al-Kutub al-'Ilmiyyah, 1994).

${ }^{61}$ Haddâd.
} 
In short, the Tunisian law of inheritance does not contradict the Sharia law considering the Tunisian government avoided conflict with the traditionalists in the early formulation of the post-independence law. Therefore, the opinions of the Mâlikî and Hanafi schools of thought were adopted by the majority of the people to be adopted and used as one of the sources in formulating the first draft of the civil law in Tunisia. ${ }^{62}$

However, in some cases, the Tunisian law of inheritance does not follow the opinion of the Mâlikî school of thought but instead goes with that of other schools of thought. It is seen, for example, from the right of 'ashabah (relatives of the deceased who are entitled to receive the remaining inheritance if available). According to the Tunisian law, the husband or wife has the right to 'ashabah share if no heir is entitled to it, sons, for example. Daughters and their children are entitled to it even though other male heirs, who are still alive, such as brothers or uncles, exist. ${ }^{63}$ These two circumstances are clearly in contrast to the principle of the Mâlikî school of thought which does not address 'ashabah to husbands/wives, daughters, and granddaughters. Excluding the two circumstances, the law of inheritance in Tunisia is subject to the provisions stipulated by the Mâlikî school of thought. ${ }^{64}$ Further, the Tunisian law of inheritance also regulates washiah wajjibah. This mandatory will is intended for grandchildren who are orphans. This only applies to the first generation of grandchildren of the deceased. ${ }^{65}$

\section{Conclusion}

Turkey and Tunisia are two countries that have dynamically reformed and reconstructed the Sharia law. However, both take different paths in regulating the law of inheritance. Turkey, for instance, applies equal inheritance rights for men and women due to the influence of the Portuguese and Russian Empires that invaded the Ottoman Empire. It has accordingly initiated to reform the state system by adopting the

\footnotetext{
${ }^{62}$ Anderson., p. 265.

63 Mahmood; Bancin., p. 293.

${ }^{64}$ Mahmood.

${ }^{65}$ Mahmood.
} 
western system in order to restore its power which was slowly weakening.

In contrast, Tunisia uses the 2:1 ratio where a man receives twice as much as a woman as stated in the Qur'an regarding the inheritance system. Such an approach is taken to maintain harmony with the majority of people who predominantly follow the Mâlikî school of thought. For this reason, Habib Bourguiba has stipulated three provisions that the drafting committee must follow in formulating the first draft of the civil law in Tunisia; 1) unifying the justice system for all Tunisian people, 2) modernizing and reforming the family law, and 3) avoiding conflict with the traditionalists by formulating the draft based on the Sharia and adopting the fiqh of Mâlikî and Hanafî as the majority of Tunisian society's schools of thought and the opinions of other schools of thought.

\section{Bibliography}

Al-Bukhârî, Muhammad Ibn Ismầil, Shahîhh al-Bukhârî, 3rd edn (Beirut: Dâr Ibn Kathîr, 1987)

al-Thabari, Muhammad Ibn Jarîr, Jâmî̀ al-Bayân Fî̀ Tảwîl al-Qur'ân, ed. by Ahmad Muhammad Shâkir (Beirut: Muassasah al-Risâlah, 2000) Al-Zuhailî, Wahbah, Al-Fiqh al-Islâmî Wa Adillatuh (Damaskus: Dâr al-Fikr)

—, Al-Tafsîr al-Munîr Fî al-Aqîdah Wa al-Shari'Ah Wa al-Manhaj (Damaskus: Dâr al-Fikr, 1998)

Anas, Mâlik Ibn, Al-Mudawwanah (Libanon: Dâr al-Kutub al-'Ilmiyyah, 1994)

Andaryuni, Lilik, 'Pembaharuan Hukum Kewarisan Islam Di Turki Dan Somalia', Hikmah, 14.1 (2018), 145-81

Anderson, J N D, 'The Tunisian Law of Personal Status', The International and Comparative Law Quarterly, 7.2 (1958), 262-79

Andriasari, Dian, 'Studi Komparatif Tentang Zina Dalam Hukum Indonesia Dan Hukum Turki', Syiar Hukum, 13.3 (2011), 265-79 Bancin, Ratih Lusiani, 'Hukum Keluarga Islam Di Tunisia', Jurnal: Penelitian Medan Agama, 9.2 (2018), 283-308 
Darmawijaya, Edi, 'Poligami Dalam Hukum Islam Dan Hukum Positif; Tinjauan Hukum Keluarga Turki, Tunisia Dan Indonesia', Gender Equality, 1.1 (2015), 27-38

Fitria, Vita, 'Hukum Keluarga Di Turki Sebagai Upaya Perdana Pembaharuan Hukum Islam', Humanika, 12.1 (2015), 1-15 <https:// doi.org/10.21831/hum.v12i1.3648>

Fuad, Mahsun, 'Dinamika Sekularisasi Dan Pembaharuan Hukum Waris Islam Di Turki', Al-Mabsûts, 13.2 (2019), 11-22<https:// doi.org/10.5281/ZENODO.3690544>

Haddâd, Al-Thâhir, Imra'atunâ Fî̀ Al-Sharî'ah Wa-Al-Mujtama' (Cairo: Dâr al-Bayân al-Mishrî, 2011)

Hasanah, Uswatun, and Chitra Latiffani, 'Kajian Pembagian Harta Gono Gini Menurut Kompilasi Hukum Islam', Journal of Science and Social Research, 1.2 (2018), 137-40 <https://doi.org/10.33330/jssr. v1i2.220>

Hasyim, Arrazy, Teologi Muslim Puritan, Geneologi dan Ajaran Salafi, 1st edn (Ciputat: Maktabah Darus Sunnah, 2017)

Huda, Miftahul, 'Ragam Bangunan Perundang-Undangan Hukum Keluarga Di Negera-Negara Muslim Modern', Al-Manahij: Jurnal Kajian Hukum Islam, 11.1 (2017), 49-60 <https://doi.org/10.24090/ mnh.v11i1.1267>

Karîm, Nâshir Ibn 'Abdul, Islâmiyyah lâ Wahabiyah (Saudi Arabia: Dâr al-Kunûz al-Asybiliyah, 2004)

Mahmood, Tahir, Family Law Reform in The Muslim World (New Delhi: The Indian Law Institute, 1972)

Nurhayati, Agustina, 'Politik Hukum (Legislasi) Hukum Keluarga Di Saudi Arabia', Ijtimaiyya, 7.1 (2014), 67-81 <https://doi.org/10.24042/ ijpmi.v7i1.918>

Osborn, David L., 'Aristotle's Conception of Justice', Notre Dame Law Review, 17.2 (1942), 129-43

Otto, Jan Michiel, Sharia and National Law in Muslim Countries Tensions and Opportunities for Dutch and EU Foreign Policy (Leiden: Leiden University Press, 2008) 
, ed., Sharia Incorporated; A Comparative Overview of the Legal Systems of Twelve Muslim Countries in Past and Present, Law, Governance, and Development Research (Leiden: Leiden Univ. Press, 2010)

Quthny, Abu Yazid Adnan, 'Reformasi Hukum Keluarga Islam Turki (Status Poligami Dalam Perspektif Teori Linguistik-Semantik Muhammad Shahrur)', Asy-Syariah, 2.2 (2016), 1-34

'Succession in Turkey' <http://www.admdlaw.com/succession-in-turkey/\#. Xvk8Bigza01> [accessed 29 June 2020]

Suma, Muhammad Amin, Keadilan Hukum Waris Islam Dalam Pendekatan Teks dan Konteks (Jakarta: Rajagrafindo Persada, 2013)

'The Tunisian Constitution', Middle East Journal, 13.4 (1959), 443-48

Turan, Ömer, 'The Turkish Diyanet Foundation.', Muslim World, 98.2/3 (2008), 370-84

Vericat, José S, Tunisia, Women's Struggle for Citizenship:, Civil Society and Constitution Making after the Arab Uprisings (International Peace Institute, 27 June 2017)

Wahib, Ahmad Bunyan, 'Reformasi Hukum Keluarga Di Dunia Muslim', Ijtihad: Jurnal Wacana Hukum Islam Dan Kemanusiaan, 14.1 (2014), $1<$ https://doi.org/10.18326/ijtihad.v14i1.1-19>

Zein, Fitriyani, 'Kekerasan Dalam Perkawinan Dan Nusyuz Dalam Hukum Keluarga Di Turki, Malaysia, Sudan, Yordan Dan Indonesia', SALAM: Jurnal Sosial Dan Budaya Syar-i, 4.1 (2017), 121-36 <https://doi. org/10.15408/sjsbs.v4i3.10290> 